\title{
Correction to: A proposal for a new temperature-corrected formula for the oxygen content of blood
}

Kiichi Hirota ${ }^{*}$, Miyahiko Murata ${ }^{2}$ and Koh Shingu ${ }^{3}$

\section{Correction to: JA Clin Rep 6, 62 (2020) https://doi.org/10.1186/s40981-020-00368-x}

Following the publication of the original article [1], the authors recognized that they need to revise some of their discussion and the explanation is provided as follows.

We thought that the coefficient 0.0031 was the Bunsen coefficient of oxygen to water measured at $37^{\circ} \mathrm{C}$, but it turned out that the Bunsen coefficient was the coefficient obtained by converting the value measured at the relevant temperature to $0^{\circ} \mathrm{C}$ under $1 \mathrm{~atm}$ conditions.

As a result, we determined that the formula calculated below is appropriate when temperature correction is performed at $37^{\circ} \mathrm{C}$.

From:

In lieu of Eq. (1), we propose a new temperature correction formula: $\mathrm{CaO} 2(\mathrm{ml} / \mathrm{dl})=1.58 \times \mathrm{Hb}(\mathrm{g} / \mathrm{dl}) \times$ $\mathrm{SaO} 2+0.0031 \times \mathrm{PaO} 2(\mathrm{mmHg})$ at $37^{\circ} \mathrm{C}$ and $1 \mathrm{~atm}$.

To:

In lieu of Eq. (1), we propose a new temperature correction formula: $\mathrm{CaO}_{2}(\mathrm{ml} / \mathrm{dl})=1.58 \times \mathrm{Hb}(\mathrm{g} / \mathrm{dl}) \times$ $\mathrm{SaO}_{2}+0.0035 \times \mathrm{PaO}_{2}(\mathrm{mmHg})$ at $37{ }^{\circ} \mathrm{C}$ and $1 \mathrm{~atm}$.

The authors apologise for this error.

\section{Author details}

'Department of Human Stress Response Science, Institute of Biomedical Science, Kansai Medical University, Hirakata, Osaka 573-1010, Japan. ${ }^{2}$ Department of Medical Care and Welfare Engineering, School of Industrial and Welfare Engineering, Tokai University, Kumamoto, Kumamoto 862-8652, Japan. ${ }^{3}$ Department of Anesthesiology, Osaka Red Cross Hospital, Osaka, Osaka 543-8555, Japan.

\footnotetext{
The original article can be found online at https://doi.org/10.1186/s40981020-00368-x.

*Correspondence: hif1@mac.com; khirota-kyt@umin.ac.jp

1 Department of Human Stress Response Science, Institute of Biomedical

Science, Kansai Medical University, Hirakata, Osaka 573-1010, Japan

Full list of author information is available at the end of the article
}

Published online: 26 January 2021

\section{Reference}

1. Hirota K, Murata M, Shingu K. A proposal for a new temperature-corrected formula for the oxygen content of blood. JA Clin Rep. 2020;6:62. https://doi. org/10.1186/s40981-020-00368-x.

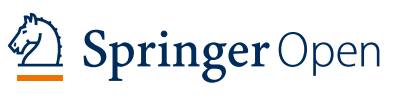

(c) The Author(s). 2021 Open Access This article is licensed under a Creative Commons Attribution 4.0 International License which permits use, sharing, adaptation, distribution and reproduction in any medium or format, as long as you give appropriate credit to the original author(s) and the source, provide a link to the Creative Commons licence, and indicate if changes were made. The images or other third party material in this article are included in the article's Creative Commons licence, unless indicated otherwise in a credit line to the material. If material is not included in the article's Creative Commons licence and your intended use is not permitted by statutory regulation or exceeds the permitted use, you will need to obtain permission directly from the copyright holder. To view a copy of this licence, visit http://creativecommons.org/licenses/by/4.0/. 